\title{
Spatial and temporal rockfall activity in a forest stand in the Swiss Prealps - A dendrogeomorphological case study
}

\author{
Simone Perret ${ }^{\mathrm{a}, *}$, Markus Stoffel ${ }^{\mathrm{b}}$, Hans Kienholz ${ }^{\mathrm{a}}$ \\ a Department of Geography, University of Berne, Applied Geomorphology and Natural Risks, Hallerstrasse 12, CH-3012 Berne, Switzerland \\ ${ }^{\mathrm{b}}$ Department of Geosciences, Geography, University of Fribourg, Groupe de Recherches en Géomorphologie, chemin du Musée 4, \\ CH-1700 Fribourg, Switzerland
}

\begin{abstract}
Rockfall is a major threat to settlements and transportation routes in large parts of the Alps. While protective forest stands in many locations undoubtedly reduce rockfall risk, little is known about the exact frequency and spatial distribution of rockfall activity in a given place or about how these parameters can be assessed. Therefore, the objective of the present study was to reconstruct rockfall events with dendrogeomorphological methods and to analyse the spatial and temporal rockfall activity in a subalpine forest stand. The study site is located in the transit zone of frequently passing, rather small rockfall fragments (mean diameter of 10 to $20 \mathrm{~cm}$ ). In all, 33 stem discs from previously felled Picea abies trees found at the foot of Schwarzenberg in Diemtigtal (Swiss Prealps) were sampled, and a total number of 301 rockfall events were dated to between A.D. 1724 and 2002.

Results showed that the spatial distribution of rockfall changed slightly with time, and that rockfall activity increased considerably over the last century. In contrast, rockfall magnitude presumably remained on a comparable level. The seasonal occurrence of rockfall showed a clear peak during the dormant season of trees, most probably in early spring. Furthermore, on a 10year moving average basis, rockfall rates were positively correlated with mean annual as well as summer and winter temperatures. This means that higher temperatures resulted in increased rockfall activity. On the other hand, no correlation with annual or seasonal precipitation totals was revealed. Overall, this study provides an appropriate method for the detailed assessment of spatial and temporal variations in rockfall activity in a given place.
\end{abstract}

Keywords: Rockfall; Protective forest; Dendrogeomorphology; Scars; Natural hazards; Swiss Prealps

\section{Introduction}

In large parts of the Alps and other mountainous regions, rockfall is a major threat to settlements and transportation routes (Varnes, 1978; Hutchinson, 1988; Flageollet and Weber, 1996; Hungr et al., 1999; Eris-

* Corresponding author. Tel.: +41 03163188 41; fax: +41 031631 8511.

E-mail address: perret@giub.unibe.ch (S. Perret). mann and Abele, 2001; Budetta, 2004). As a consequence, measures have to be taken for public protection. In some cases, technical measures may help to reduce rockfall risk. However, in many places, protective forest stands turn out to provide the most sustainable form of protection and at a lower price than technical measures. For this reason, the protective function of mountain forest stands has recently gained particular interest (Bebi et al., 2001; Berger et al., 2002; Dorren et al., 2004a). Although the general 
protective effect of mountain forests against rockfall is not questioned now (Brang, 2001; Berger and Rey, 2004), much is still unknown about the assessment of rockfall frequency and distribution in a given place, as well as about the ideal properties of a protective forest stand (Stoffel et al., in press). Therefore, a better understanding of major processes in mountain forests is needed (Kienholz, 1995; Kräuchi et al., 2000; Naylor et al., 2002).

Several studies have assessed the interaction between rockfall and forest on a local scale, but not on the scale of individual trees (Jahn, 1988; Zinggeler et al., 1991; Mani and Kläy, 1992; Dorren et al., 2004b; Perret et al., 2004; Frehner et al., 2005). In addition, research has mainly focused on short-term observations of contemporary rockfall activity in the field (Luckman, 1976; Douglas, 1980; Gardner, 1983; Matsuoka and Sakai, 1999), or on lichenometric analyses (Luckman and Fiske, 1995; McCarroll et al., 1998). Moreover, as tree-ring analyses have the potential to yield yearly resolved data on past geomorphic events (DeGraff and Agard, 1984), dendrogeomorphological methods were repeatedly used to study different processes. These methods were first developed by Alestalo (1971) and further refined by Shroder (1980) and Butler et al. (1987). They take advantage of the fact that trees immediately react to external disturbances by mass movements.

So far, dendrogeomorphological studies have primarily concentrated on the analysis of snow avalanches (e.g., Butler and Malanson, 1985; Rayback, 1998; Hebertson and Jenkins, 2003), debris flows (e.g., Strunk, 1995; Baumann and Kaiser, 1999; Stoffel et al., 2005c), landslides (e.g., Jacoby et al., 1992; Fantucci and Sorriso-Valvo, 1999; Stefanini, 2004), and rock-glacier movements (Giardino et al., 1984; Carter et al., 1999; Bachrach et al., 2004). On the other hand, rockfall processes have only rarely been investigated using tree-ring analysis (Gsteiger, 1993; Stoffel, in press). Nonetheless, as recently shown by Stoffel et al. (2005b) for a protective forest in the southern Swiss Alps, dendrogeomorphological methods have the potential to yield data on past rockfall activity on a very detailed spatial scale, as well as over a considerably long time period. However, similar studies for other parts of the Swiss Alps are so far lacking.

The objective of the present study therefore was (i) to reconstruct rockfall events with dendrogeomorphological methods and (ii) to analyse the spatial distribution of rockfall as well as (iii) to assess the temporal rockfall activity in a subalpine forest stand in the Swiss
Prealps. The investigated stand is situated at the foot of a high cliff in the transit zone of frequently passing, rather small rockfall fragments (mean diameter of 10 to $20 \mathrm{~cm}$ ). Spatial analyses were performed by interpolating the number of rockfall injuries per tree. Temporal analyses comprised the calculation of rockfall rates, trends in rockfall activity and their correlations with mean annual or seasonal temperatures, and precipitation totals.

\section{Material and methods}

\subsection{Study site and sampling}

The study presented was performed at the site of Schwarzenberg, which is located in Diemtigtal in the Swiss Prealps (Bernese Oberland, 46 $36^{\prime}$ N, $7^{\circ} 33^{\prime}$ E, $1250 \mathrm{~m}$ asl; see Fig. 1). Schwarzenberg is a $\sim 400-\mathrm{m}$ high Triassic limestone cliff, at the foot of which is found a deep, SE-exposed talus slope with a slope angle of about $40^{\circ}$. This talus slope with a relatively homogenous, stony surface is forested with a Picea abies (L.) Karst stand (Polygalo chamaebuxi Piceetum) that also contains Sorbus aria (L.) Crantz, Sorbus aucuparia L., and Acer pseudoplatanus L. According to Ott et al. (1997), this forest type is usually met in montane to subalpine environments in the northern limestone Alps on dry, alkaline, steep, and south-facing sites.

The study site, covering an area of 0.3 ha, is located in the uppermost part of the talus slope in the transit zone of frequent rockfall fragments. Falling rocks only have a mean diameter of about 10 to $20 \mathrm{~cm}$. Rockfall is the only geomorphic process on the slope and thus processes such as landslides, debris flows or snow avalanches have never been witnessed. Investigations on the site started in 2001 with a detailed field inventory and analysis of rockfall injuries visible on stem surfaces (Perret et al., in press). Within that study, analysis of 157 trees allowed identification of 1704 rockfall injuries.

Because of a severe bark beetle outbreak succeeding the storm Lothar (WSL and BUWAL, 2001), a major deforestation was undertaken at the foot of Schwarzenberg in autumn 2002. As a result, 33 of the previously studied Picea abies trees in the lower part of the investigated area (see Fig. 1) were felled during the deforestation campaign. From each of the 33 Picea abies tree stumps, which remained in the field, one stem disc (cross-section) was sampled at a mean height of $30 \mathrm{~cm}$ above ground (up-slope side of the trunk). This sampling was performed independently of the 

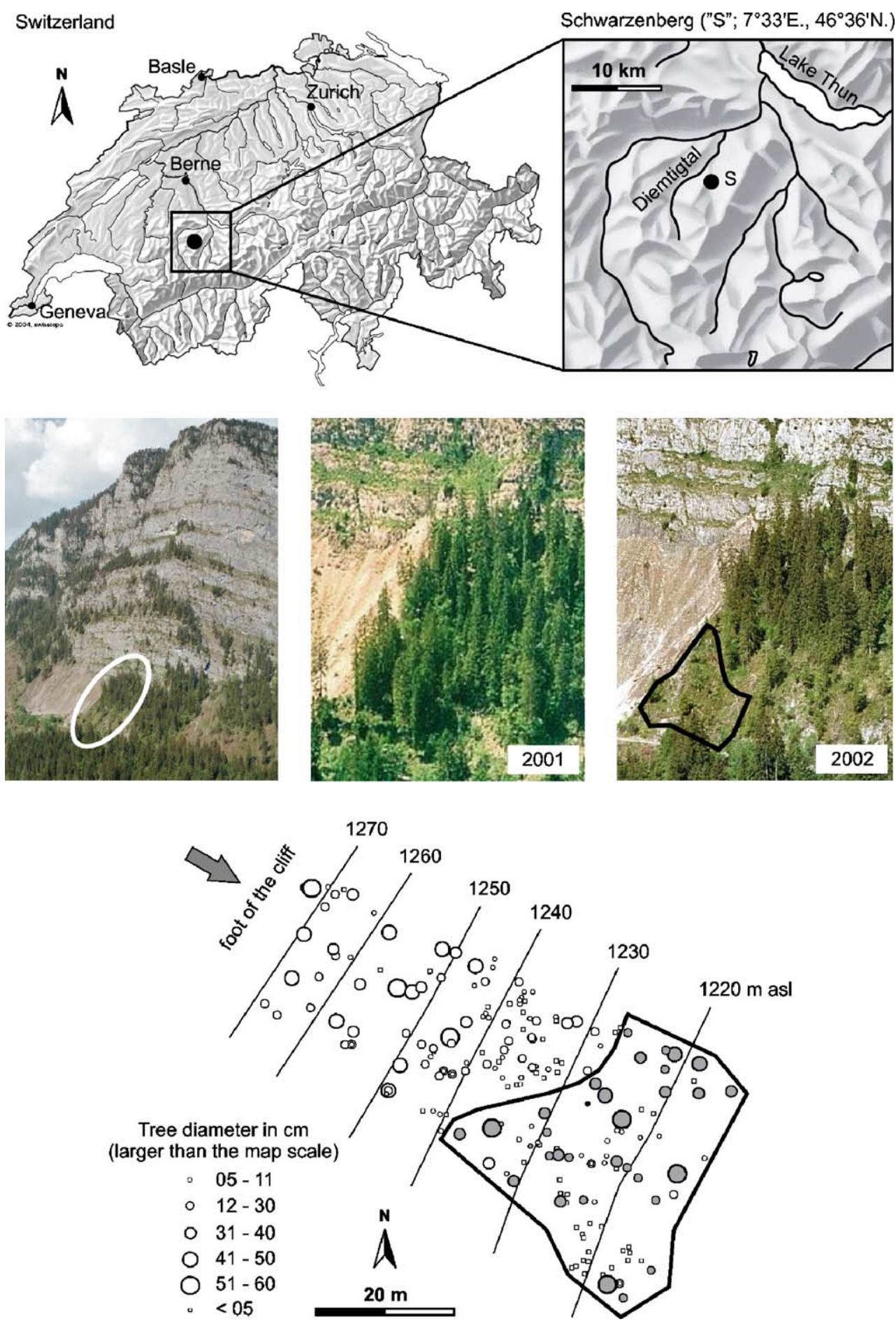

Fig. 1. Study site at Schwarzenberg in Diemtigtal (Bernese Oberland, Swiss Prealps). The location of the study site is given in the maps on top. The pictures in the middle show the rock cliff of Schwarzenberg and the study site at its foot before (A.D. 2001) and after (A.D. 2002) deforestation. The map at the bottom shows the tree distribution in the investigated stand. Stem discs from the Picea abies trees marked in grey (within the black perimeter) were sampled for dendrogeomorphological analysis. The grey arrow indicates the main fall direction of rocks. 
presence or absence of scars visible on the stem surface. Diameters of the single stem discs ranged from 9 to 55 $\mathrm{cm}$, with a mean diameter of $34 \mathrm{~cm}$. Thereafter, the 33 samples were sanded in the laboratory so as to allow the dendrogeomorphological analyses described in the following.

\subsection{Recording past rockfall events}

Depending on their size, velocity, and energy, falling, rolling, or bouncing rock fragments can injure trees by breaking, tilting, or scarring stems. As a reaction to a rock impact, Picea abies trees may produce reaction wood, traumatic rows of resin ducts, or callus tissue. These signs remain visible in tree-ring sequences and can be analysed with dendrogeomorphological methods (Bräuning, 1995; Schweingruber, 1996, 2001). As a result, analysis allows the reconstruction of rockfall events in a given area.

Stem discs sampled at Schwarzenberg were first processed as proposed by Wiles et al. (1996) and Bräker (2002). Ring widths were measured and growth curves cross-dated (in order to correct the age of the samples where applicable), before tree-rings were dated. Ring width measurements were performed with a digital LINTAB positioning table connected to a Leica stereomicroscope and to TSAP 3.0 software (Time Series Analysis and Presentation by Rinntech, 2005).
In a second step, samples were visually inspected to identify evidence of past rockfall events, allowing reconstruction of spatial and temporal rockfall patterns. Reconstructions included the recording of scars visible on the stem disc, as well as traumatic rows of resin ducts belonging to injuries located elsewhere in the stem. Fig. 2 shows an example of a sampled stem disc with several rockfall injuries. As no geomorphic processes other than rockfall are encountered in the investigated stand, every tree injury was considered to result from a rock impact. Similarly, the storm events of 1990 and 1999 (storms Vivian and Lothar; WSL and BUWAL, 2001) did not leave signs in the tree-ring sequences analysed. Resin ducts were only considered the result of rockfall activity if they formed traumatic, compact, continuous and tangential rows. All scars and traumatic rows of resin ducts were dated with yearly precision. For the scars, the seasonal timing of the rockfall event was also determined, following the procedure described by Stoffel et al. (2005a). Furthermore, descriptive parameters such as injury width, presence of injured wood, and stage of healing were registered for the scars.

\subsection{Spatial and temporal data analysis}

As rockfall consists of single falling rock fragments, a single rock may only impact trees along its trajectory. Thus, some rocks hit just one tree on their way down
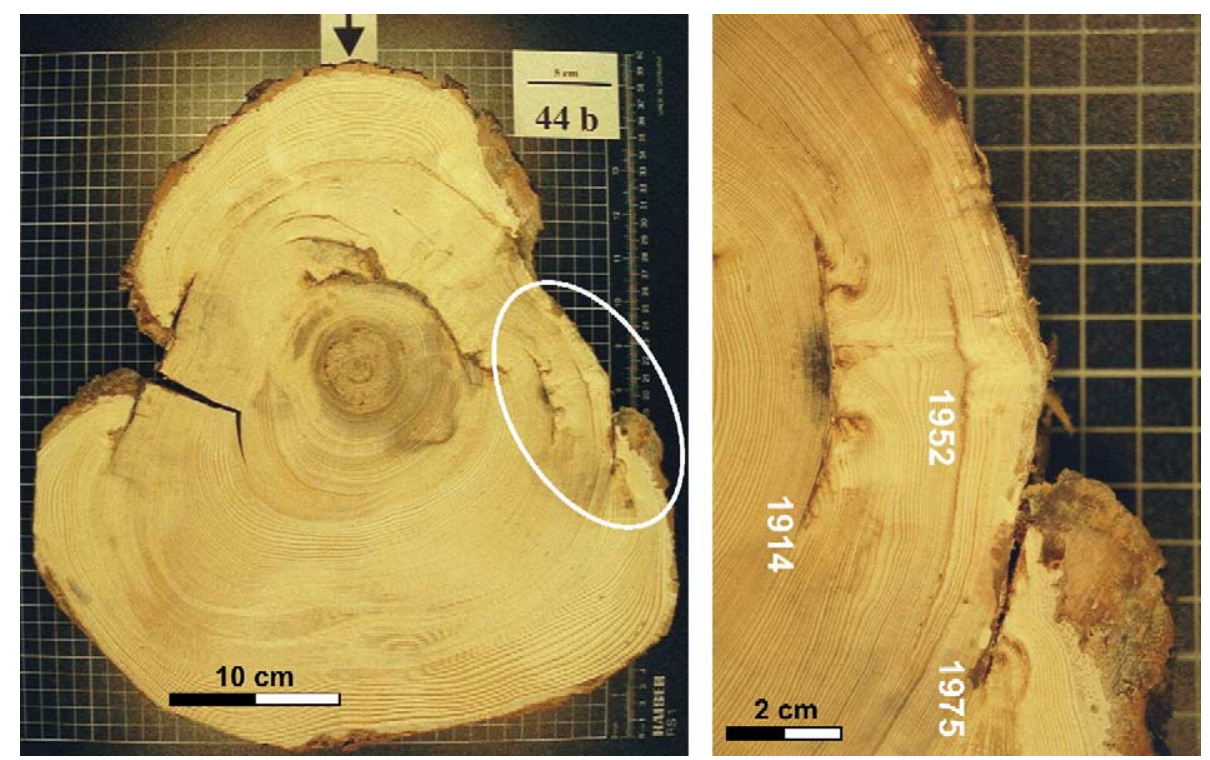

Fig. 2. Example of a Picea abies stem disc sampled at Schwarzenberg with several rockfall injuries (5 scars and 10 traumatic rows of resin ducts). Sampling height of $18 \mathrm{~cm}$, disc diameter of $37 \mathrm{~cm}$, pith at A.D. 1762, death at A.D. 2002, age of 240 years. The black arrow indicates the up-slope side of the trunk. The second picture shows a detail from the disc with three scars. 
the slope, whereas others might impact several trees, or no trees at all. This is why dendrogeomorphological reconstructions can only approximate past rockfall activity. Within this study we nonetheless assume that every rock impact represents one rockfall event. Thus, once all rockfall events were reconstructed, data were analysed with respect to their spatial and temporal distribution between A.D. 1881 and 2000.

In order to illustrate spatial patterns of rockfall activity, the number of injuries per tree was interpolated with ArcView GIS 3.2 (ESRI, 2005). Tree coordinates were available from a previous study (Perret et al., in press) and could be linked with the number of reconstructed injuries per tree. The distribution of injuries was then visualised by performing a linear interpolation (inverse distance weighting) of the number of injuries per tree with the 10 nearest neighbouring trees. The resulting interpolated number of injuries per $\mathrm{m}^{2}$ was presented in a map. Prior to the deforestation on the study site, a similar interpolation was performed based on field inventory data. This interpolation shows the number of injuries per $\mathrm{m}^{2}$ that are visible on the stem surface of all living trees (Perret et al., in press). Therefore, comparing data obtained from tree-ring analysis with data from the field inventory was possible. Varying spatial patterns of rockfall activity over time were furthermore shown by dividing data from tree-ring analysis (A.D. 1881 to 2000) into four time sequences of 30 years each.

For further exploration of temporal rockfall activity, a rockfall rate was calculated following Stoffel et al. (2005b). This annual rockfall rate (a proxy for the actual rate) represents the number of rockfall injuries per meter tree diameter exposed to rockfall in 1 year. As illustrated in Fig. 3, the rockfall rate for, e.g., 1930, was obtained by dividing the total number of injuries recorded in the stem discs for 1930 by the sum of all tree diameters in that year. The diameter of a tree in 1930 was calculated by multiplying the age of the tree at that time with the mean annual increment of the tree. As to determine whether the annual rockfall rate significantly changed over the last century, it was tested with the Mann-Kendall trend test (two-tailed $Z$ test, significance level at 0.01).

This trend test was also applied in the analysis of temperatures and precipitation from nearby climate stations. From mean monthly temperatures for the period A.D. 1901 to 2000 at Château d'Oex $\left(46^{\circ} 29^{\prime} \mathrm{N}\right.$, $07^{\circ} 09^{\prime} \mathrm{E}, 985 \mathrm{~m}$ asl; MeteoSwiss, 2005), mean annual as well as summer (April to September) and winter (October to March) temperatures were calculated. Châ-
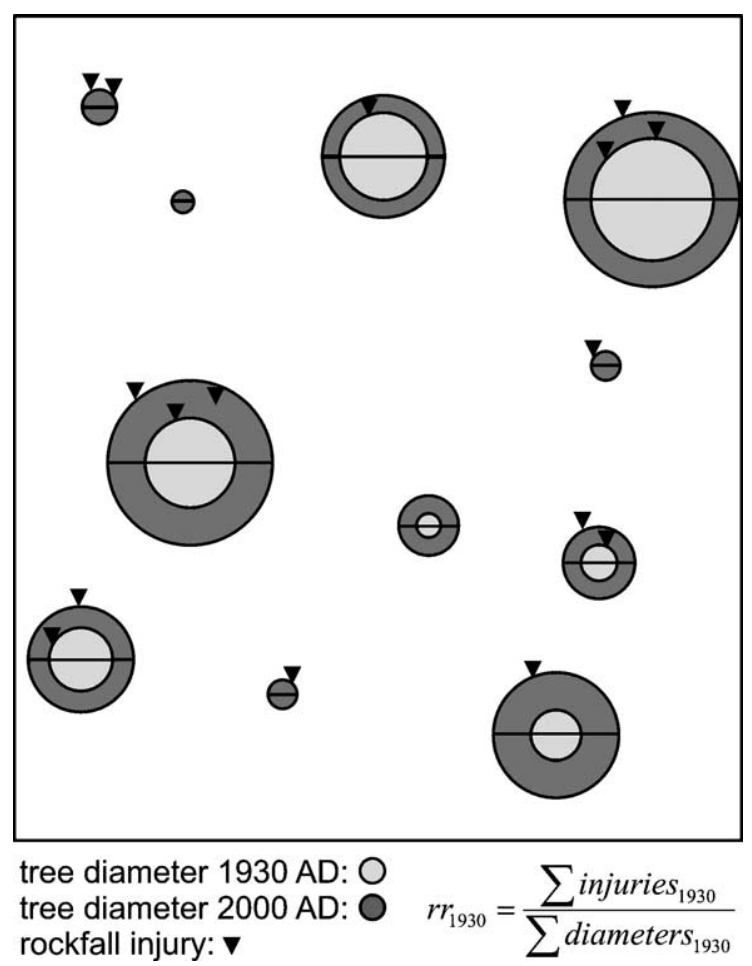

Fig. 3. Schematic representation of the annual rockfall rate in a given perimeter. The annual rockfall rate represents the number of rockfall injuries per meter tree diameter exposed to rockfall in one year. For example, the rockfall rate for 1930 is obtained by dividing the total number of injuries recorded in the stem discs for 1930 by the sum of all tree diameters in that year.

teau d'Oex was the closest climate station with a sufficiently long series of temperature measurements. Moreover, monthly precipitation totals from Boltigen, Erlenbach i.S. and Frutigen (BEF; MeteoSwiss, 2005) were used for the same period so as to derive annual as well as summer and winter precipitation totals. Within this study, BEF represents the averaged precipitation totals recorded at the meteorological stations of Boltigen $\left(46^{\circ} 37^{\prime} \mathrm{N}, 07^{\circ} 23^{\prime} \mathrm{E}, 855 \mathrm{~m}\right.$ asl), Erlenbach i.S. ( $46^{\circ} 40^{\prime} \mathrm{N}, 07^{\circ} 33^{\prime} \mathrm{E}, 683 \mathrm{~m}$ asl), and Frutigen $\left(46^{\circ} 35^{\prime} \mathrm{N}, 07^{\circ} 39^{\prime} \mathrm{E}, 815 \mathrm{~m}\right.$ asl). As can be seen from Fig. 7, these stations are located in a triangle around Schwarzenberg.

After trend analyses, mean annual, summer and winter temperatures, as well as precipitation totals from these nearby climate stations were furthermore used for comparison with the rockfall rate. Thus, the 10 -year moving average for the annual rockfall rate as well as for mean temperatures and precipitation totals was calculated. Finally, Pearson's correlations between the averaged rockfall rate and the averaged climate parameters were derived and tested statistically (twotailed $t$-test at a significance level of 0.01). 


\section{Results}

\subsection{Characteristics of trees and their rockfall injuries}

As given in Table 1, the 33 Picea abies trees had a mean age of 180 years at sampling height (about $30 \mathrm{~cm}$ above ground level). The youngest tree reached this height in A.D. 1884 (i.e., 118 years before sampling), and the oldest one in A.D. 1724, (i.e., 278 years prior to sampling). Thus, starting in 1884 , all trees sampled were available for analysis over more than one century. Cross-dating of the samples showed that only four trees died shortly before sampling in 2002 .

The oldest evidence of past rockfall activity was recorded in 1767 through the presence of a traumatic row of resin ducts, whereas the oldest scar was dated to 1850. Table 2 provides the total and mean number of scars and traumatic rows of resin ducts. Overall, 301 rockfall events were reconstructed, and many more traumatic rows of resin ducts (214) than scars (87) were identified. In 1994 nine injuries were registered, which is the highest number of impacts found in 1 single year, followed by eight injuries in 1970, 1975, and 1988. The mean size (i.e., width on the stem disc) of scars amounted to $3.8 \mathrm{~cm}$ (minimum $0.2 \mathrm{~cm}$, maximum $14 \mathrm{~cm}$ ). In $26 \%$ of all scars, rock impacts had not only injured bark and the underlying cambium, but previously formed wood as well. Interestingly, most scars $(87 \%)$ identified on the cross-sections were already totally overgrown at the time of sampling. While some of these overgrown scars were still visible on the stem surface, $63 \%$ of all scars were no longer visible from outside. Thus, all these hidden scars would have been missed if only injuries visible on the stem surface had been assessed. Further data on injury healing and visibility of scars are presented in Stoffel and Perret (submitted for publication).

For reasons of sample depth, only those rockfall events occurring between 1881 and 2000 were used for spatial and temporal analysis. Consequently, as indicated in Table 2, the number of scars (75) and traumatic rows of resin ducts (175) was reduced. The proportion of scars $(30 \%)$ and traumatic rows of resin ducts $(70 \%)$ for this time period is given in Fig. 4A. Furthermore, Fig. 4B shows the seasonal distribution of

Table 1

Age of trees at sampling height (about $30 \mathrm{~cm}$ above ground level)

\begin{tabular}{lll}
\hline & Pith age (years) & Pith age (A.D.) \\
\hline Mean & 180 & \\
Minimum & 118 & 1884 \\
Maximum & 278 & 1724 \\
\hline
\end{tabular}

Table 2

Number of reconstructed rockfall events

\begin{tabular}{lll}
\hline Number of. .. & A.D. & A.D. \\
& $1724-2002$ & $1881-2000$ \\
\hline (1) Scars & 87 & 75 \\
Mean per stem disc & $2-3$ & \\
Minimum/Maximum per stem disc & $0 / 9$ & \\
Discs without scars & 4 & \\
(2) Traumatic rows of resin ducts & 214 & 175 \\
Mean per stem disc & $6-7$ & \\
Minimum/Maximum per stem disc & $1 / 20$ & \\
Discs without traumatic rows of & 0 & \\
resin ducts & & 250 \\
(3) Dated rockfall events & 301 &
\end{tabular}

the scars registered between 1881 and 2000. Obviously, most scars $(74 \%)$ were caused during the dormant season (D) of trees, approximately lasting from October to May at Schwarzenberg. In contrast, $15 \%$ of scars emerged during earlywood growth (E) and only $11 \%$ during latewood growth (L).

\subsection{Spatial rockfall distribution for different time periods}

Fig. 5A gives the results of the spatial interpolation of rockfall injuries registered on the stem discs on the one hand (i.e., data from tree-ring analysis), and the injuries recorded on the stem surfaces on the other (i.e., data from field inventory). Trees included in analysis are marked in grey. Overall, the results suggest that, with the field inventory, a slightly larger number of injuries were registered than with tree-ring analysis. Moreover, the spatial pattern of data gained from treering analysis appears to be just the opposite of field inventory data. In tree-ring data, most injuries were located on trees in the northern part of the investigated perimeter. In contrast, field inventory data showed the largest number of injuries in the southern part.

Fig. 5B provides a time series (1881 to 2000) that shows the spatial distribution of rockfall injuries as reconstructed with tree-ring analysis. Every map represents 30 years of rockfall activity and gives the interpolated number of injuries per $\mathrm{m}^{2}$. The first map covers the time period from 1881 to 1910 , when very few injuries (about 0-1 injury per $\mathrm{m}^{2}$ ) occurred in the whole area. The second map shows the distribution of injuries caused between 1911 and 1940. In this period, slightly more injuries were identified, i.e. predominantly $1-2$ injuries per $\mathrm{m}^{2}$. Similarly to the first time sequence, injuries are rather evenly distributed. In the third time sequence ranging from 1941 to 1970 , a distinct increase in the number of injuries can be observed. The predo- 
(A)

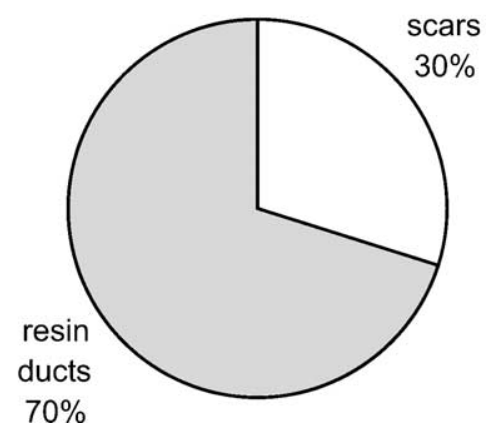

(B)

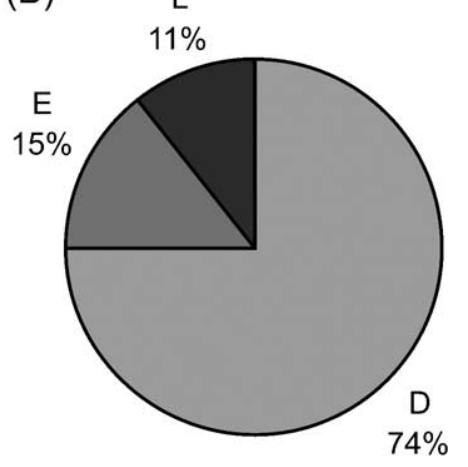

Fig. 4. (A) Percentage of scars and traumatic rows of resin ducts registered in the 33 stem discs between 1881 and 2000. (B) Seasonal distribution of scars $(\mathrm{D}=$ dormancy, $\mathrm{E}=$ earlywood, $\mathrm{L}=$ latewood $)$.

minating number of injuries rises to $2-4$, again quite evenly distributed over the area. The last map covers the time period from 1971 to 2000 and shows a clear increase in the number of injuries up to a maximum of 6-8 injuries per $\mathrm{m}^{2}$. This time, however, the spatial distribution of injuries is no longer homogeneous, with most injuries occurring in the northern part of the investigated perimeter. As a consequence, rockfall activity over the last 30 years appears to have played a major role in the pattern gained from tree-ring analysis (1881-2000; see Fig. 5A). Overall, the time series presented also suggests a distinct increase in rockfall activity over the last century.

\subsection{Temporal rockfall activity and its correlation with climate parameters}

The apparent increase in rockfall activity was further explored by calculating annual rockfall rates between 1881 and 2000, represented by the histogram in Fig. 6 . As can be seen, the rockfall rate (i.e., number of rockfall injuries per meter of exposed tree diameter) steadily increased over the twentieth century. Simultaneously, the number of years without any rockfall event became less frequent. Apart from 1986, at least one rockfall event was registered for every year since 1952 . The highest rockfall rate was calculated for 1970 .

To further underline the increase of rockfall events, the 10-year moving average of the annual rockfall rate, showing a clear positive trend, is provided with the line chart in Fig. 6. In order to verify this trend, the annual rockfall rate was tested with the Mann-Kendall trend test. In fact, as can be seen from Table 3, the rockfall rate shows a statistically highly significant, positive trend $(p=0.005)$. Table 3 further illustrates that mean annual as well as summer and winter temperatures at Château d'Oex show a highly significant, positive trend between 1910 and 2000 as well. In contrast, precipitation totals for BEF (mean of Boltigen, Erlenbach i.S., Frutigen; for details, see Section 2.3) apparently have no significant trends at all.

As shown in Fig. 7, the evolution of the rockfall rate was compared with that of mean temperatures and precipitation totals (based on 10-year moving averages). The calculated correlation coefficients between the 10-year moving averages of the rockfall rate and the climate parameters mentioned are provided in Table 4. Data clearly revealed that mean annual as well as summer and winter temperatures are positively correlated with the rockfall rate at a high level of statistical significance ( $p=0.000$ for all correlations). Thus, high temperatures are connected with a high rockfall rate, whereas low temperatures result in decreased rockfall activity. On the other hand, precipitation totals showed no significant correlation with the rockfall rate.

\section{Discussion}

The objective of the study presented was to reconstruct rockfall events with dendrogeomorphological methods and to analyse the spatial and temporal rockfall activity in a subalpine forest stand. The study site is exposed to frequent but small rockfall events (mean rock diameter of 10 to $20 \mathrm{~cm}$ ). Therefore, 33 stem discs from Picea abies trees were sampled at the foot of Schwarzenberg in Diemtigtal (Swiss Prealps), and a total number of 301 rockfall events were dated starting from A.D. 1724. For reasons of sample depth, spatial and temporal analyses were limited to the period A.D. 1881 to 2000 , reducing the number of dated rockfall events to 250. About one-third of past rockfall events were dated with scars visible at sampling height and two-thirds through the presence of traumatic rows of 


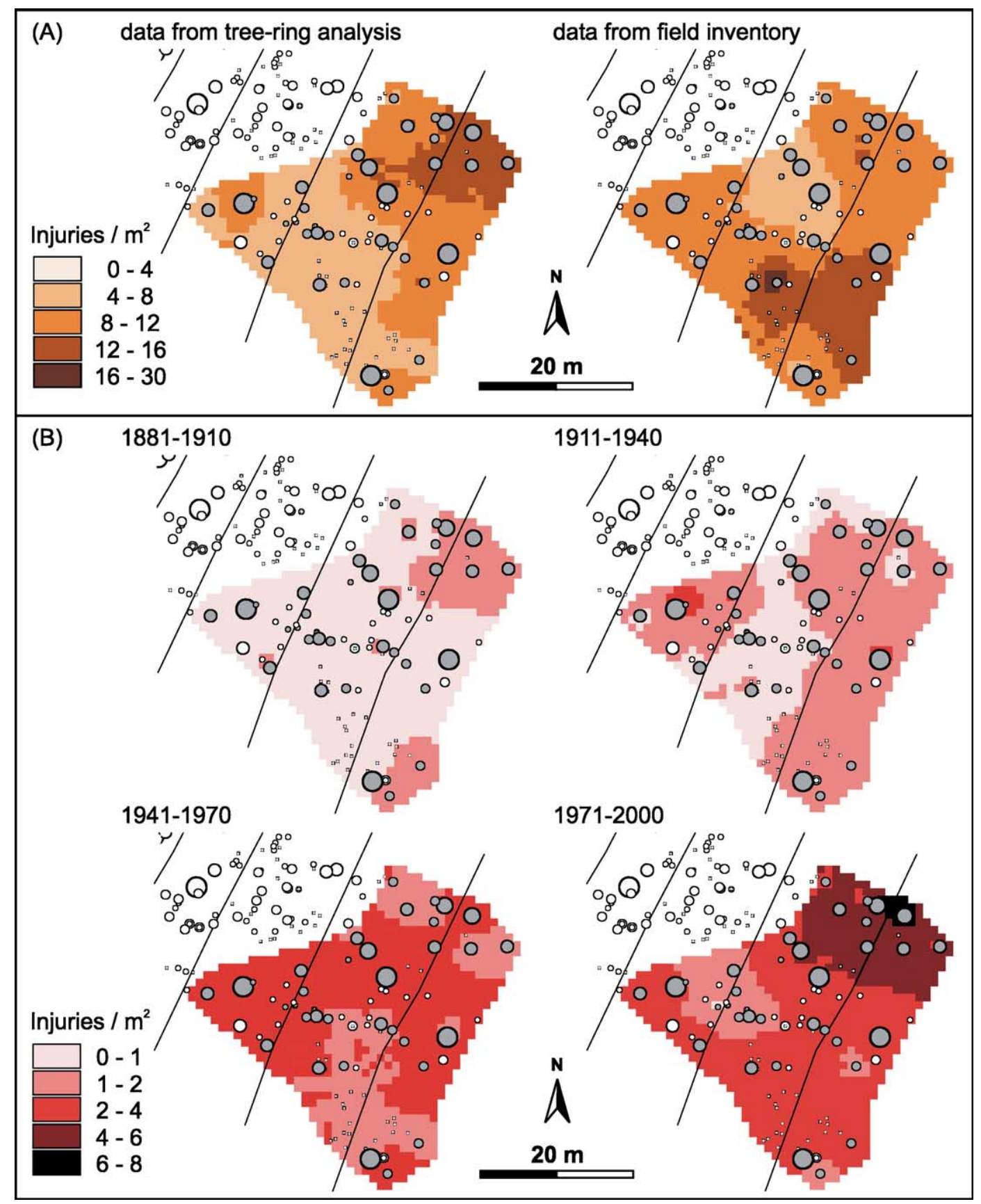

Fig. 5. Reconstructed spatial rockfall distribution in the investigated perimeter (see Fig. 1). Maps show the interpolated (linear, with 10 neighbouring trees) number of injuries per $\mathrm{m}^{2}$. (A) Data from tree-ring analysis versus data from field inventory. (B) Data from tree-ring analysis divided into four time sequences covering 30 years each.

resin ducts. The latter belong to scars located elsewhere on the stem.

The seasonal occurrence of rockfall activity on the slope shows a clear peak during the dormant season of trees. From field observations, we assume that most rockfall occurs in early spring, just before the growing season starts locally with the formation of earlywood cells in the Picea abies trees. These results from Schwarzenberg are in agreement with findings published by Stoffel et al. (2005a) for a study site in the southern Swiss Alps, which yielded a clear peak of rockfall activity in dormancy as well. However, because of the lower altitude of the study site at Schwarzenberg as well as the absence of permafrost, the peak during 


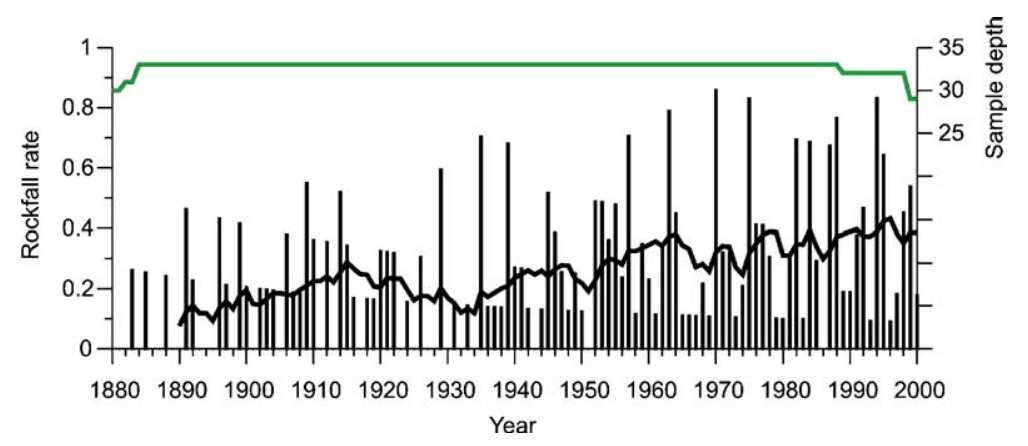

Fig. 6. Annual rockfall rate (number of injuries per $1 \mathrm{~m}$ exposed tree diameter) and its 10 -year moving average, as well as the number of samples analysed (=sample depth).

dormancy is less pronounced here. Based on reconstructed rockfall events and field observations, we believe that a maximum in rockfall activity from the 400$\mathrm{m}$ high rock cliff at Schwarzenberg occurs right after the melt-out of the rock cliff in early spring. This finding is similar to the one by Matsuoka and Sakai (1999) for their study site in the Japanese Alps.

The comparison of spatial rockfall distribution derived from tree-ring analysis with that from field inventory data yielded quite different patterns. While dendrogeomorphological data indicated enhanced rockfall activity in the northern part of the investigated area, field data showed more activity in the southern part. For the southern sector, this discrepancy is slightly reduced when, for field data, only those injuries located within the first $60 \mathrm{~cm}$ above ground are taken into account. This restriction gives preference to those injuries identified close to the mean sampling height of stem discs at about $30 \mathrm{~cm}$. Nonetheless, considerable differences between data from tree-ring analysis and data from field inventory still persist in the northern part of the investigated area. We believe that these differences most probably result from the presence of several hidden injuries, which are no longer visible on stem surfaces but could be reconstructed on cross-sections. As $63 \%$ of all scars identified on stem discs could no longer be seen on the stem surface, this scenario appears to be quite realistic. In addition, as previously proposed by Perret et al. (in press), some of the injuries registered in the field might have been caused by more than one rock impact but were classified as only one scar. In the case of overgrown wounds, distinguishing between different scars at the same location is especially difficult.

Furthermore, analysis of spatial rockfall patterns for different time periods indicated a clear increase in rockfall activity over the last century. Data also revealed that the reconstructed peak in rockfall activity for the northern part of the investigated area was predominantly caused between 1971 and 2000. Nonetheless, several of these rather recent scars could obviously no longer be identified on the stem surface. Therefore we suppose that the relatively small rockfall fragments occurring during the usual low magnitude but high frequency events would tend to cause quite small scars, which would completely heal over within only a few years. These results lead us to believe that field inventory data focusing on scars visible on the stem surface of trees (e.g., Jahn, 1988; Dorren et al., 2004a; Perret et al., in press) probably give a reasonable idea of current rockfall activity or signs of unusually large events in the past. At the same time, such field inventories run the risk of neglecting long-term variations in spatial rockfall activity.

Table 3

Mann-Kendall trend test (two-tailed $Z$ test, significance level at 0.01 ) for rockfall rate, temperature and precipitation

\begin{tabular}{llll}
\hline Mann-Kendall trend test for. . & $Z$ & $p$ & Trend \\
\hline (1) Annual rockfall rate, Schwarzenberg $^{\mathrm{a}}$ & 2.807 & 0.005 & Significant, positive \\
(2) Mean annual temperature, Château d'Oex & & Significant, positive \\
Mean summer temperature (April-Sept) & 6.966 & 0.000 & Significant, positive \\
Mean winter temperature (Oct-March) & 5.527 & 0.000 & Significant, positive \\
(3) Annual precipitation total, BEF ${ }^{\mathrm{a}, \mathrm{b}}$ & 5.436 & 0.000 & Not significant \\
Summer precipitation total (April-Sept) & 0.748 & 0.455 & Not significant \\
Winter precipitation total (Oct-March) & 0.372 & 0.710 & Not significant \\
\hline
\end{tabular}

a A.D. 1901-2000

b Mean of Boltigen, Erlenbach i.S., and Frutigen (for details, see text and Fig. 7). 

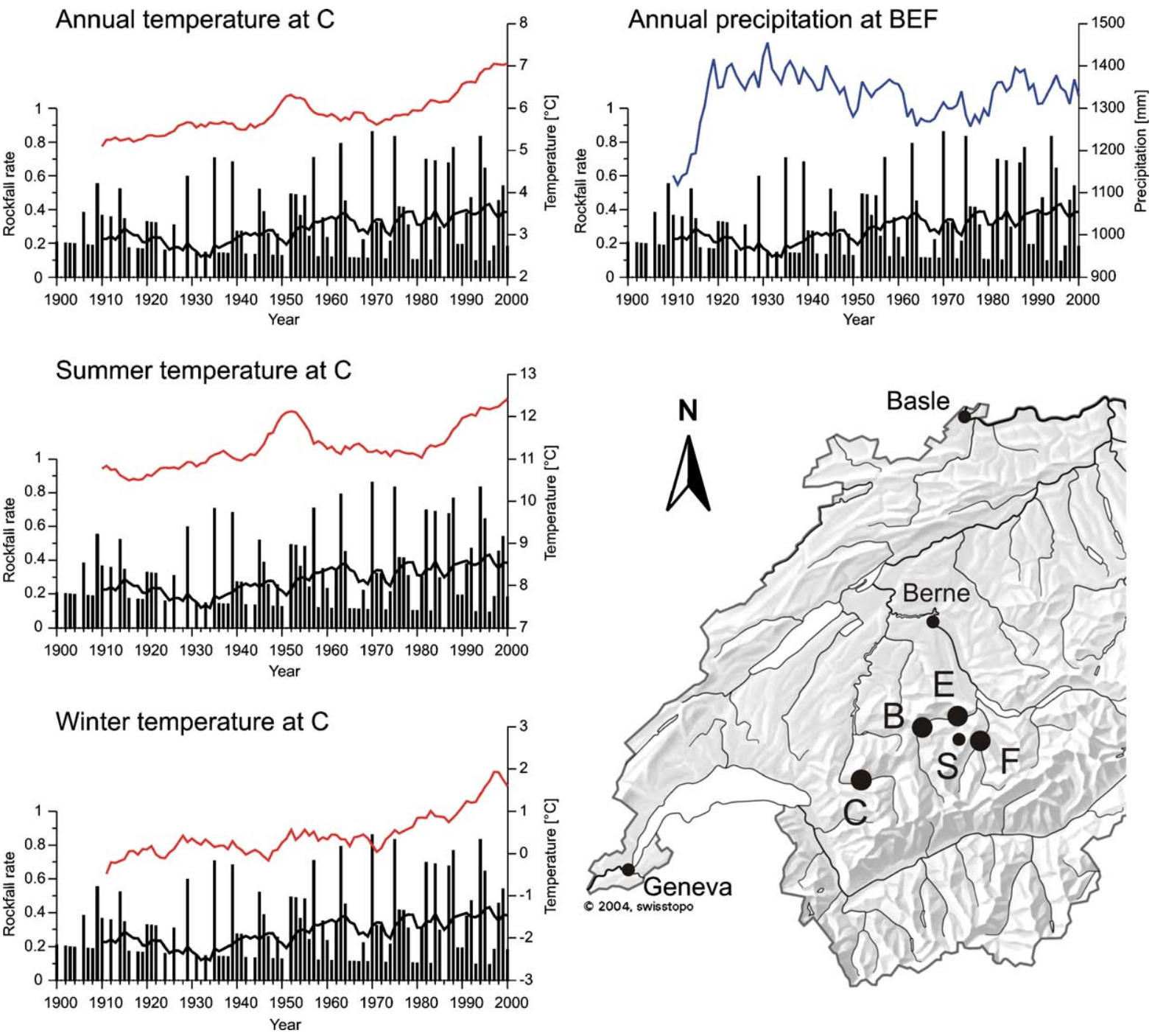

Fig. 7. Correlation between the 10-year moving averages of the rockfall rate at Schwarzenberg ("S" in the map of Switzerland; details see Fig. 1) and the annual as well as summer and winter temperatures of Château d'Oex ("C"), and the annual precipitation of BEF from 1900 to 2000 ("B"= Boltigen, "E"=Erlenbach i.S., "F"=Frutigen; for details, see Section 2.3).

Similarly to results obtained from spatial analysis, data from temporal analysis clearly showed a positive trend in the calculated rockfall rate. This indicates that rockfall activity significantly increased over the twentieth century. Data further showed a steady increase in the number of rockfall events per year since the 1950s,

Table 4

Pearson's correlation ( $r$; two-tailed $t$-test, significance level at 0.01 ) of rockfall rate at Schwarzenberg with temperature and precipitation

\begin{tabular}{|c|c|c|c|}
\hline Correlation between 10 -year moving average rockfall rate and... & $r$ & $p$ & Correlation \\
\hline (1) 10-year moving average temperature, Château d'Oex ${ }^{a}$ & 0.650 & 0.000 & Significant, positive \\
\hline 10-year moving average summer temperature (April-Sept) & 0.558 & 0.000 & Significant, positive \\
\hline 10-year moving average winter temperature (Oct-March) & 0.655 & 0.000 & Significant, positive \\
\hline (2) 10 -year moving average precipitation, $\mathrm{BEF}^{\mathrm{a}, \mathrm{b}}$ & 0.176 & 0.095 & Not significant \\
\hline 10-year moving average summer precipitation (April-Sept) & 0.235 & 0.025 & Not significant \\
\hline 10-year moving average winter precipitation (Oct-March) & -0.005 & 0.965 & Not significant \\
\hline
\end{tabular}

${ }^{a}$ A.D. $1910-2000$.

${ }^{\mathrm{b}}$ Mean of Boltigen, Erlenbach i.S., and Frutigen (for details, see text and Fig. 7). 
whereas years without rockfall events simultaneously decreased. Thus, at the end of the twentieth century a rather high rockfall frequency with typically several events per year can be observed. In contrast, we must assume (based on the size of rockfall injuries and of fresh rockfall fragments deposited on the slope) that the magnitude of rockfall has remained unchanged at a rather low level.

Results furthermore showed that, at the same time as rockfall frequency increased, the mean annual as well as summer and winter temperatures in the investigated area rose as well. Explanations for the positive trend in temperatures are for example given in OcCC (2003) and will not be further discussed here. The highly significant positive correlation (based on 10-year moving averages) that emerged between the annual rockfall rate and mean annual as well as seasonal temperatures, clearly indicates that rockfall from the Schwarzenberg rock cliff tends to be triggered by higher temperatures. Consequently, in line with findings of Matsuoka and Sakai (1999), temperature presumably plays a predominant role at Schwarzenberg. In this sense, increased winter temperatures might, for example, favour the occurrence of frequent freeze-thaw cycles in the rock cliff and thus facilitate weathering and the production of rockfall fragments (Raetzo-Brülhart, 1997). However, for a detailed exploration of frost action in the rock cliff, local climate parameters need to be known. In addition, as recently shown by, e.g., Gruber et al. (2004) or Carey and Woo (2005), temperatures within a rock cliff as well as local topographic conditions play an important role in determining whether freezing occurs or not. As a consequence, local conditions should be further assessed so as to receive more specific data on weathering and rockfall triggering at Schwarzenberg.

Unlike temperatures, precipitation totals showed no significant correlation with the rockfall rate. In contrast to common assumptions, increased precipitation totals apparently did not result in more rockfall events at Schwarzenberg. Although single thunderstorms might well trigger rockfall (Raetzo-Brülhart, 1997), such events remain only poorly represented by precipitation totals. On the other hand, results obtained at Schwarzenberg are in agreement with data gathered by Matsuoka and Sakai (1999), who could not identify correlations between rockfall activity and precipitation either.

Besides climatic parameters, many other - especially short-term-influencing factors may drive or inhibit rockfall activity on a local scale. As a consequence and despite the reasonably good correlation between temperature and rockfall rate (10-year moving averages), iden- tifying clear connections between the reconstructed rockfall activity at Schwarzenberg and the extraordinarily warm seasons observed in Switzerland for single years (Pfister, 1999) still remains quite difficult. On a yearly basis, both the method chosen for analysis (i.e., dendrogeomorphology) as well as the large number of interacting factors that influence rockfall triggering on a local scale would still preclude analysis of rockfall-climate interactions in greater detail.

Finally, we believe (like Stoffel et al., 2005b) that the calculated rockfall rate is a valuable indicator for assessing past rockfall activity, as it takes account of the tree diameter exposed to rockfall fragments as well as its gradual change with time. Since rockfall usually consists of single falling, bouncing, or rolling rock fragments, some rocks may, however, hit just one tree, while others might injure several trees, or no trees at all. Furthermore, we have to assume that in the stem discs sampled at about $30 \mathrm{~cm}$ above ground, injuries located very high on the stem as well as rather small scars were not detected through the analysis of traumatic rows of resin ducts. The question remains as to how far away from the location of an impact traumatic rows of resin ducts can be detected. Nevertheless, despite all these influencing factors, the rockfall rate may provide a realistic approximation of how rockfall activity in a given place varied over time.

\section{Conclusion}

The results of this study clearly showed that in the investigated forest stand at the foot of a rock cliff (Swiss Prealps) the spatial rockfall distribution changed slightly over the last decades and that rockfall activity increased considerably over the last century. In contrast, rockfall magnitude presumably remained on a comparably low level. The seasonal timing of rockfall activity indicated a clear peak during the dormant season of trees, most probably in early spring. Moreover, based on 10-year moving averages, a highly significant positive correlation between mean temperatures and the rockfall rate at Schwarzenberg was identified. This means that higher temperatures result in increased rockfall activity. On the other hand, no correlation with precipitation totals was revealed.

Overall, this study provided an appropriate method for the assessment of spatial and temporal variations in rockfall activity in a given place. Results also showed that dendrogeomorphological analyses clearly have the potential to produce detailed results on annual or decadal fluctuations of rockfall activity over a long time period, as well as on varying spatial rockfall patterns. 
Altogether, this study has taken a step in the direction of a better understanding of rockfall processes on forested slopes. However, conclusions concerning the protective effect of an ideal forest stand remain, so far, rather limited. Further case studies as well as experimental tests on other sites are needed to improve and refine methods used within this study as well as the overall understanding of rockfall-forest interactions.

\section{Acknowledgements}

The authors would like to thank the Swiss Federal Office for Education and Science for funding the European scientific project ROCKFOR-Rockfall and Forest Interrelation (QLK5-CT-2000-01302). MeteoSwiss is gratefully acknowledged for providing the climate data. Special thanks go to Franz Baumgartner for his professional help with the sampling of stem discs, as well as to Marc Baumgartner, Michelle Bollschweiler, and Bernhard Wehren for their great support in the field, lab, and office.

\section{References}

Alestalo, J., 1971. Dendrochronological interpretation of geomorphic processes. Fennia 105, 1-139.

Bachrach, T., Jakobsen, K., Kinney, J., Nishimura, P., Reyes, A., Laroque, C.P., Smith, D.J., 2004. Dendrogeomorphological assessment of movement at Hilda rock glacier, Banff National Park, Canadian Rocky Mountains. Geogr. Ann. 84A (1), 1-9.

Baumann, F., Kaiser, K.F., 1999. The Multetta debris fan, eastern Swiss Alps: a 500-year debris flow chronology. Arct. Alp. Res. 31 (2), 128-134.

Bebi, P., Kienast, F., Schönenberger, W., 2001. Assessing structures in mountain forests as a basis for investigating the forests' dynamics and protective function. For. Ecol. Manag. 145, 3-14.

Berger, F., Rey, F., 2004. Mountain protection forests against natural hazards and risks: new French developments by integrating forests in risk zoning. Nat. Hazards 33, 395-404.

Berger, F., Quetel, C., Dorren, L.K.A., 2002. Forest: a natural protection mean against rockfall, but with which efficiency? The objectives and methodology of the ROCKFOR project. Final Proc. Int. Conf. Interpraevent in Matsumoto, Japan. Interpraevent, Klagenfurt, Austria, pp. 815-826.

Bräker, O.U., 2002. Measuring and data processing in tree-ring research - a methodological introduction. Dendrochronologia 20 (1-2), 203-216.

Brang, P., 2001. Resistance and elasticity: promising concepts for the management of protection forests in the European Alps. For. Ecol. Manag. 145, 107-119.

Bräuning, A., 1995. Zur Anwendung der Dendrochronologie in den Geowissenschaften. Die Erde 126, 189-204.

Budetta, P., 2004. Assessment of rockfall risk along roads. Nat. Hazards Earth Syst. Sci. 4, 71-81.

Butler, D.R., Malanson, G.P., 1985. A history of high-magnitude snow avalanches, southern Glacier National Park, Montana, U.S.A. Mt. Res. Dev. 5 (2), 175-182.
Butler, D.R., Malanson, G.P., Oelfke, J.G., 1987. Tree-ring analysis and natural hazard chronologies: minimum sample sizes and index values. Prof. Geogr. 39 (1), 41-47.

Carey, S.K., Woo, M.K., 2005. Freezing of subarctic hillslopes, Wolf Creek Basin, Yukon, Canada. Arct. Antarct. Alp. Res. 37 (1), $1-10$.

Carter, R., Leroy, S., Nelson, T., Laroque, C.P., Smith, D.J., 1999. Dendroglaciological investigations at Hilda Creek rock glacier, Banff National Park, Canadian Rocky Mountains. Géogr. Phys. Quat. 53, 365-371.

DeGraff, J.V., Agard, S.S., 1984. Defining geologic hazards for natural resources management using tree-ring analysis. Environ. Geol. Water Sci. 6 (3), 147-155.

Dorren, L.K.A., Berger, F., Imeson, A.C., Maier, B., Rey, F., 2004a. Integrity, stability and management of protection forests in the European Alps. For. Ecol. Manag. 195, 165-176.

Dorren, L.K.A., Maier, B., Putters, U.S., Seijmonsbergen, A.C., 2004b. Combining field and modelling techniques to assess rockfall dynamics on a protection forest hillslope in the European Alps. Geomorphology 57, 151-167.

Douglas, G.R., 1980. Magnitude frequency study of rockfall in Co. Antrim, Northern Ireland. Earth Surf. Processes Landf. 5, $123-129$.

Erismann, T.H., Abele, G., 2001. Dynamics of Rockslides and Rockfalls. Springer, Berlin.

ESRI (Environmental System Research Institute), 2005. ArcView. http://www.esri.com/software/arcgis/arcview/index.html.

Fantucci, R., Sorriso-Valvo, M., 1999. Dendrogeomorphological analysis of a slope near Lago, Calabria (Italy). Geomorphology 30, $165-174$.

Flageollet, J.C., Weber, D., 1996. Fall. In: Dikau, R., Schrott, L., Brunsden, D., Ibsen, M. (Eds.), Landslide Recognition. Wiley, West Sussex, U.K., pp. 13-28.

Frehner, M., Wasser, B., Schwitter, R., 2005. Nachhaltigkeit und Erfolgskontrolle im Schutzwald. Wegleitung für Pflegemassnahmen in Wäldern mit Schutzfunktion. Bundesamt für Umwelt, Wald und Landschaft, Bern.

Gardner, J.S., 1983. Rockfall frequency and distribution in the highwood Pass area, Canadian Rocky Mountains. Z. Geomorph. N.F. 27 (3), 311-324.

Giardino, J.R., Shroder Jr., J.F., Lawson, M.P., 1984. Tree-ring analysis of movement of a rock-glacier complex on Mount Mestas, Colorado, U.S.A. Arct. Alp. Res. 16 (3), 299-309.

Gruber, S., Hoelzle, M., Haeberli, W., 2004. Rock-wall temperatures in the Alps: modelling their topographic distribution and regional differences. Permafr. Periglac. Process. 15, 299-307.

Gsteiger, P., 1993. Steinschlagschutzwald: Ein Beitrag zur Abgrenzung, Beurteilung und Bewirtschaftung. Schweiz. Z. Forstwes. 144 (2), 115-132.

Hebertson, E.G., Jenkins, M.J., 2003. Historic climate factors associated with major avalanche years on the Wasatch Plateau, Utah. Cold Reg. Sci. Technol. 37, 315-332.

Hungr, O., Evans, S.G., Hazzard, J., 1999. Magnitude and frequency of rock falls along the main transportation corridors of southwestern British Colombia. Can. Geotech. J. 36, 224-238.

Hutchinson, J.N., 1988. Morphological and geotechnical parameters of landslides in relation to geology and hydrogeology. In: Bonnard, C. (Ed.), Landslides. Balkema, Rotterdam, pp. 3-35.

Jacoby, G.C., Williams, P.L., Buckley, B.M., 1992. Tree ring correlation between prehistoric landslides and abrupt tectonic events in Seattle, Washington. Science 258, 1621-1623. 
Jahn, J., 1988. Entwaldung und Steinschlag. Final Proc. Int. Conf. Interpraevent in Graz, Austria. Interpraevent, Klagenfurt, Austria, pp. $185-198$.

Kienholz, H., 1995. Gefahrenbeurteilung und -bewertung-auf dem Weg zu einem Gesamtkonzept. Schweiz. Z. Forstwes. 146 (9), $701-725$.

Kräuchi, N., Brang, P., Schönenberger, W., 2000. Forests of mountainous regions: gaps in knowledge and research needs. For. Ecol. Manag. 132, 73-82.

Luckman, B.H., 1976. Rockfalls and rockfall inventory data: some observations from Surprise Valley, Jasper National Park. Earth Surf. Process. 1, 287-298.

Luckman, B.H., Fiske, C.J., 1995. Estimating long-term rockfall accretion rates by lichenometry. In: Slaymaker, O. (Ed.), Steepland Geomorphology. Wiley, Chichester, pp. 233-255.

Mani, P., Kläy, M., 1992. Naturgefahren an der Rigi-Nordlehne. Die Beurteilung von Naturgefahren als Grundlage für die waldbauliche Massnahmenplanung. Schweiz. Z. Forstwes. 143, 131-147.

Matsuoka, N., Sakai, H., 1999. Rockfall activity from an alpine cliff during thawing periods. Geomorphology 28, 309-328.

McCarroll, D., Shakesby, R.A., Matthews, J.S., 1998. Spatial and temporal patterns of Late Holocene rockfall activity on a Norwegian talus slope: lichenometry and simulation-modelling approach. Arct. Alp. Res. 30, 51-60.

MeteoSwiss, 2005. On-line database from MeteoSwiss. http://www. meteoswiss.ch/en/.

Naylor, L.A., Viles, H.A., Carter, N.E.A., 2002. Biogeomorphology revisited: looking towards the future. Geomorphology 47, 3-14.

OcCC (Organe consultatif sur les changements climatiques) (Ed.), 2003. Extremereignisse und Klimaänderung. OcCC, Bern.

Ott, E., Frehner, M., Frey, H.U., Lüscher, P., 1997. Gebirgsnadelwälder: Ein praxisorientierter Leitfaden für eine standortgerechte Waldbehandlung. Paul Haupt, Bern.

Perret, S., Dolf, F., Kienholz, H., 2004. Rockfalls into forests: analysis and simulation of rockfall trajectories - considerations with respect to mountainous forests in Switzerland. Landslides 1, $123-130$.

Perret, S., Baumgartner, M., Kienholz, H., in press. Inventory and analysis of tree injuries in a rockfall-damaged forest stand. Eur. J. For. Res.

Pfister, C., 1999. Wetternachhersage: 500 Jahre Klimavariationene und Naturkatastrophen (1496-1995). Paul Haupt, Bern.

Raetzo-Brülhart, H., 1997. Massenbewegungen im Gurnigelflysch und Einfluss der Klimaänderung. PhD Dissertation, Univ of Fribourg, Fribourg.

Rayback, S.A., 1998. A dendrogeomorphological analysis of snow avalanches in the Colorado Front Range, USA. Phys. Geogr. 19 (6), 502-515.

Rinntech, 2005. LINTAB_Precision ring by ring. http://www.rinntech.com/Products/Lintab.htm.
Schweingruber, F.H., 1996. Tree rings and environment. Dendroecology. Paul Haupt, Bern.

Schweingruber, F.H., 2001. Dendroökologische Holzanatomie. Paul Haupt, Bern.

Shroder Jr., J.F., 1980. Dendrogeomorphology: review and new techniques of tree-ring dating. Prog. Phys. Geogr. 4, 161-188.

Stefanini, M.C., 2004. Spatio-temporal analysis of a complex landslide in the northern Apennines (Italy) by means of dendrochronology. Geomorphology 63, 191-202.

Stoffel, M., in press. A review of studies dealing with tree rings and rockfall activity: The role of dendrogeomorphology in natural hazard research. Nat. Hazards.

Stoffel, M., Perret, S., submitted for publication. Reconstructing past rockfall activity with tree rings: some methodological considerations. Dendrochronologia.

Stoffel, M., Lièvre, I., Monbaron, M., Perret, S., 2005a. Seasonal timing of rockfall activity on a forested slope at Täschgufer (Swiss Alps) - a dendrochronological approach. Z. Geomorphol. $49,89-106$.

Stoffel, M., Schneuwly, D., Bollschweiler, M., Lièvre, I., Myint, M., Monbaron, M., 2005b. Analyzing rockfall activity (1600-2002) in a protection forest-a case study using dendrogeomorphology. Geomorphology 68 (3-4), 224-241.

Stoffel, M., Lièvre, I., Conus, D., Grichting, M., Raetzo, H., Gärtner, H., Monbaron, M., 2005c. 400 years of debris flow activity and triggering weather conditions: Ritigraben VS, Switzerland. Arct. Antarct. Alp. Res. 37 (3), 387-395.

Stoffel, M., Wehrli, A., Kühne, R., Dorren, L.K.A., Perret, S., Kienholz, H., in press. Quantifying the protective effect of mountain forests against rockfall using a 3D simulation model. For. Ecol. Manag.

Strunk, H., 1995. Dendrochronologische Methoden zur Ermittlung der Murfrequenz und Beispiele ihrer Anwendung. Roderer Verlag, Regensburg.

Varnes, D., 1978. Slope movement, types and processes. Special Report, vol. 176. National Academy of Sciences, Washington, DC, pp. 11-33.

Wiles, G.C., Calkin, P.E., Jacoby, G.C., 1996. Tree-ring analysis and quaternary geology: principles and recent applications. Geomorphology 16, 259-272.

WSL (Eidg. Forschungsanstalt für Wald, Schnee und Landschaft), BUWAL (Bundesamt für Umwelt, Wald und Landschaft) (Eds.), 2001. Lothar. Der Orkan 1999. Ereignisanalyse. WSL, BUWAL, Birmensdorf, Bern.

Zinggeler, A., Krummenacher, B., Kienholz, H., 1991. Steinschlagsimulation in Gebirgswäldern. In: Monbaron, M., Haeberli, W. (Eds.), Modelle in der Geomorphologie - Beispiele aus der Schweiz, vol. 3. Geographisches Institut Universität Freiburg (CH), pp. 61-70. 